\title{
Wireless Body Area Network untuk Detak Jantung dan Suhu Tubuh
}

\author{
Rahayu Puji Lestari ${ }^{* 1}$, Diah Risqiwati ${ }^{2}$, Zamah Sari ${ }^{3}$ \\ 1,2,3Teknik Informatika/Universitas Muhammadiyah Malang \\ rahayupujilestarii25@gmail.com¹ ${ }^{*}$,rsqiwati@umm.ac.id ${ }^{2}$, zamahsari@umm.ac.id ${ }^{3}$
}

\begin{abstract}
Abstrak
Wireless Body Area Network (WBAN) adalah suatu sistem terpadu yang terdiri atas sekelompok modul sensor yang terdistribusi dan terhubung secara nirkabel pada suatu topologi jaringan tertentu dan berfungsi untuk mengekstrak dan berbagi informasi untuk diolah sesuai bidang aplikasinya. Kesehatan adalah hal yang sangat penting untuk selalu diperhatikan mengingat kondisi tubuh manusia tidak selalu dalam kondisi sehat. Sekarang permasalahan dari kesehatan tubuh manusia tidak hanya dari kuman, bakteri ataupun virus yang dibawa oleh udara. Melainkan, dari pola hidup dan asupan yang masuk kedalam tubuh kita. Dalam jangka panjang atau pendek akan berpangaruh buruk dalam tubuh kita bila dalam pola hidup kita kurang atau tidak sehat, tanpa megenal usia, penyakit apa saja bisa menyerang kita. Yakni serangan jantung dan suhu tubuh. Untuk menjamin ketepatan diagnosis dari dokter, dibutuhkan suatu mekanisme untuk mengirimkan sinyal fisiologis dari pasien melalui jaringan telekomunikasi Berangkat dari permasalahan yang ada, dapat dibuat sebuah sistem untuk menghitung detak jantung dan suhu tubuh secara berkala. Dengan Sensor detak jantung (pulse sensor) dan sensor suhu tubuh (ds18b20) akan dipasang di tubuh si pasien, data yang dibaca oleh sensor kemudian dikirimkan ke android dengan menggunakan modul wireless ESP8266 yang tersambung dengan sensor. Android menerima data yang dikirimkan oleh modul wireless dan menampilkan data. Mengimplementasikan sistem dengan aplikasi berbasis android dengan fitur history.
\end{abstract}

Kata Kunci: Wireless Body Area Network (WBAN), Pulse Sensor, ds18b20, ESP8266

\begin{abstract}
WBAN is an integrated system which consists of a distributed group of censory modul and connected to a topology of specific network wirelessly and is use to extract various information to be processed as the application field. Health is a highly important aspect that needed to be cared regards human's unstable health state. Nowadays, health problem came not only from germ, bacteria, or viruses but alos ceme from by life style and eating habits. These, problem could affect our life regards any ages, whether for short or ling term. Any disease could harm us, such as heart stroke and body temperature. A mechanism which send patient's phisiologcial signal through telecommunication network is needed to ensure doctor's diagnostic. Based on this problem a system to count heartbeat and body temperature periodically could be made. Heartbeat censor (pulse sensor) and body temperature sensor (ds18b20) will be pair in patient's body. The information and data will be read by the censor and will be send to android using wireless ESP8266 which connected to the censor. Android receives and shows data which have been sent by wireless modul, to implement system with android based application using history features.
\end{abstract}

Keywords: Wireless Body Area Network (WBAN), Pulse Sensor, ds18b20, ESP8266

\section{Pendahuluan}

Kesehatan adalah hal yang sangat penting untuk selalu diperhatikan mengingat kondisi tubuh manusia tidak selalu dalam kondisi sehat. Untuk menjamin ketepatan diagnosis dari suatu penyakit maka diperlukan suatu mekanisme untuk mengirimkan sinyal fisiologis dari pasien melalui jaringan telekomunikasi [1]. Wireless Body Area Network (WBAN) adalah suatu sistem terpadu yang terdiri atas sekelompok modul sensor yang terdistribusi dan terhubung secara nirkabel pada suatu topologi jaringan tertentu dan berfungsi untuk mengekstrak dan berbagi informasi untuk diolah sesuai bidang aplikasinya [2].

Tujuan dari penelitian ini adalah untuk mengukur suhu tubuh dan detak jantung secara wireless dan dikirimkan melalui modul wireless ESP8266 dalam bentuk aplikasi android. 
Fungsi utama jantung yaitu memberikan oksigen keselruh tubuh dan membersihkan seluruh tubuh dari karbondioksida. Denyut jantung yang optimal untuk setiap individu berbedabeda tergantung pada kapan waktu mengukur detak jantung tersebut (setelah berolahraga atau pada saat istirahat). Variasi atau perbedaan dalam detak jantung sesuai dengan jumlah oksigen yang diperlukan oleh tubuh waktu itu. Jumlah denyut jantung normal pada orang dewasa yang sehat, disaat istirahat sekitar 60-100 denyut per menit [3].

Suhu tubuh normal yakni $36,3-37,7^{\circ} \mathrm{C}$, suhu tubuh normal dapat berubah- ubah sepanjan hari. Suhu tubuh terendah terutama terjadi pada pagi hari, suhu tubuh dapat meningkat hingga $0,6{ }^{\circ} \mathrm{C}$ pada sore hari. Suhu tubuh juga dapat dipengaruhi oleh aktivitas harian [4].

Oleh karena itu terdapat masalah, yakni bagaimana merancang aplikasi berbasis android untuk menampilkan dan menyimpan hasil data pembacaan sensor suhu tubuh dan detak jantung yang dikirim menggunakan modul wireless ESP8266.

Beberapa penelitian terkait tentang topik monitoring jantung atau suhu tubuh secara wireless pernah dilakukan sebelumnya seperti penelitian oleh Agung Budi Wijaya dan Achmad Subhan Kahlilullah, pada tahun 2010 yang berjudul "Rancang Bangun Alat Pengukur Detak Jantung Dan Suhu Tubuh Manusia Berabasis Komunikasi Bluetooth" [4]. Pada penelitian yang lain "Perancangan Pengukur Detak Jantung Dan Suhu Tubuh Berbasis Arduino Serta Smartphone Android" oleh Eddy Riyanto [3]. Pada Penelitian selanjutnya "Rancang Bangun Prototipe Monitoring Suhu Tubuh Manusia Berbasis O.S Android Menggunakan Koneksi Bluetooth" [5].

Sensor suhu dan detak jantung akan dipasang di tubuh si pasien, data yang dibaca oleh sensor kemudian dikirimkan ke android dengan menggunakan modul wireless ESP8266 yang tersambung dengan sensor. Android menerima data yang dikirimkan oleh modul wireless dan menampilkan data. Dalam tugas akhir ini mengimplementasikan sistem dengan aplikasi berbasis android dengan fitur history. Dan akan membahas proses pengiriman data tersebut, menguji ketahanan modul wireless tersebut dan menguji kemampuan android apakah android mampu untuk menampung data dari dua sensor sekaligus dan akan di uji dalam jangka waktu yang berbeda- beda.

\section{Metode Penelitian \\ 2.1 Analisis Sistem}

Analisis sistem yakni untuk mengetahui apa saja yang diperlukan dalam pengerjaan tugas akhir ini, dan memastikan apakah fitur yang digunkan sudah cukup untuk pengambilan data sensor.

\subsection{Perancangan Sistem}

Sistem pengambilan data dari sensor detak jantung dan suhu tubuh pada tugas akhir ini memliki cara kerja yang sama saja seperti pada umumnya. Yaitu, bila pada detak jantung sensor membaca aliran darah dengan bantuan sensor cahaya dan melakukan penghitungan terhadap aliran darah yang ditangkap sensor, kemudian sistem akan mengirim data ke aplikasi android melalui wireless sebagai informasi yang akan didisplay. Media sensor yang digunkan untuk detak jantung yaitu pulse sensor.

Dan untuk cara kerja pengambilan data suhu tubuh pun juga sama seperti pada umumnya. Yakni sensor membaca suhu tubuh dan melakukan penghitungan terhadap suhu yang dikeluarkan dan yang ditangkap oleh sensor, kemudian sistem akan mengirimkan data hasil dari sensor ke aplikasi android melalui jaringan wireless sebagai informasi yang akan didisplya. Media sensor yang digunakan untuk suhu tubuh yaitu $d s 18 b 20$. Sedangkan, untuk meda kontroler yang digunakan ialah ESP8266 yang memerlukan tegangan bekisar 1 - 3 volt (sensitive).

\subsection{Perancangan Perangkat Keras}

Selanjutnya dilakukan perancangan perangkat keras. Pada perancangan perangkat keras terdiri dari sensor detak jantung, suhu tubuh dan wireless. Gambar 1 dibawah ini merupakan gambaran arsitektur perancangan perangkat keras.

Keterangan:

1. Pulse sensor yang digunakan untuk mengambil data sensor detak jantung

2. DS18B20 yang diguanakn untuk mengambil data sensor suhu tubuh

3. Sensor Node

4. ESP8266 atau modul wireless yang digunakan untuk mengirim data sensor

REPOSITOR, Vol. 2, No. 3, Maret 2020: 269-276 
5. Android untuk menampilkan data hasil dari sensor.

6. $\rightarrow$ Menggunakan Jaringan Wireless

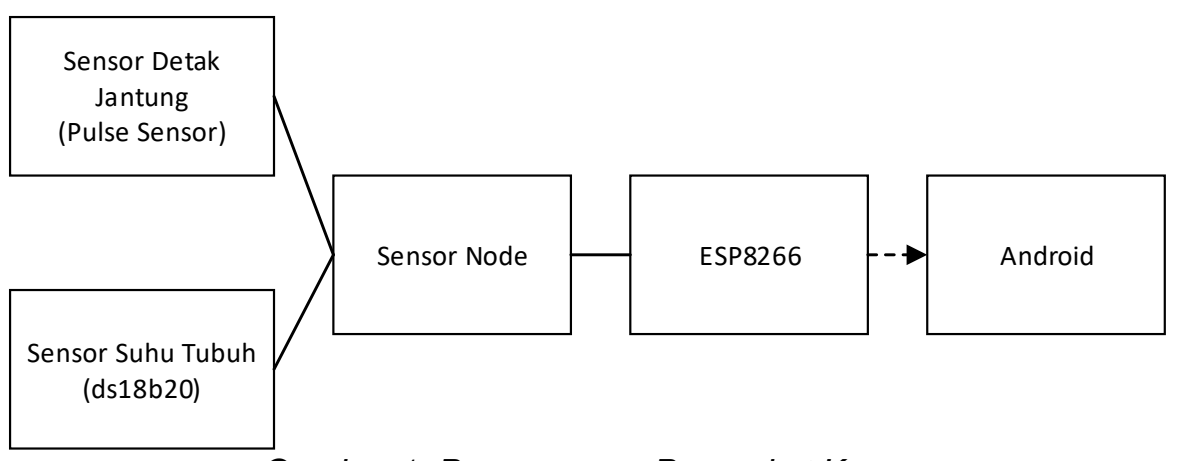

Gambar 1. Perancangan Perangkat Keras

\subsection{Perancangan Perangkat Lunak}

Pada tahapan Gambar 2 ini yang dilakukan yaitu perancangan perangkat lunak yang digunakan sebagai acuan saat implementasinya.

Keterangan :

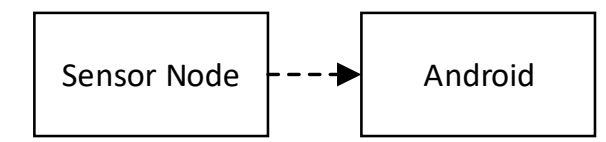

Gambar 2. Perancangan Perangkat Lunak

1. Perangkat lunak

2. Perangkat lunak pada android

$\rightarrow$ Menggunakan Jaringan Wireless

\subsection{Diagram Alur}

Deskripsi Kerja secara keseluruhan dari sistem ini, sistem ini akan mulai beroperasi ketka diberikan sumber tegangan mulai dari baterai, power bank, atau usb laptop ke ESP8266, ds18b20, dan pulse sensor. Dengan adanya tegangan pada sistem kontroller, data dapat dikirim dari ESP8266 ke aplikasi yang ditampilkan pada aplikasi android. Adapun rancangan flowchart alur dari sistem pada Gambar 3.

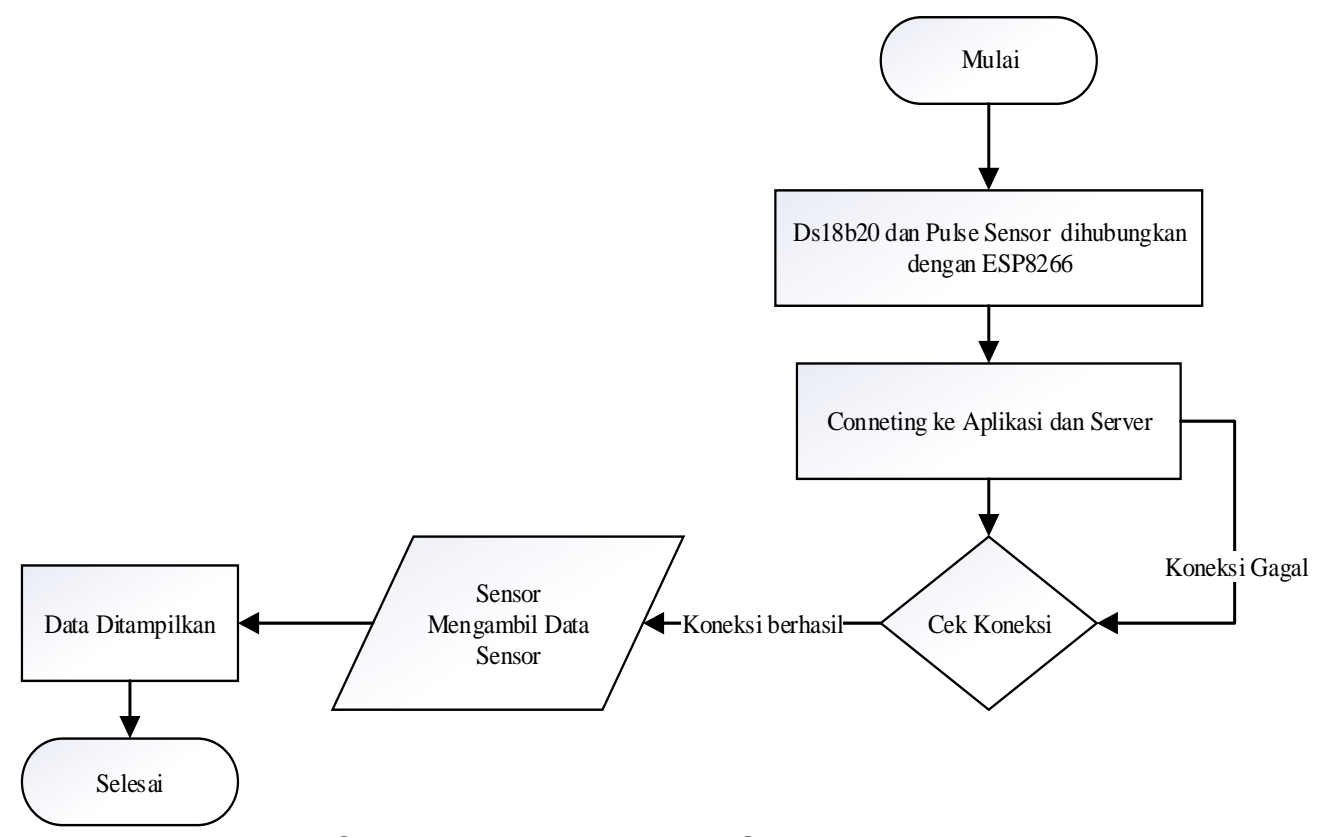

Gambar 3. Flowchart Alur Sistem Rangkaian

Wireless Body Area Network Untuk Detak Jantung... Rahayu Puji Lestari, Diah Risqiwati, Zamah Sari 
Pada Gambar 3 adalah flowchart alur sistem rangkaian yang menjelsakan sensor ds18b20 dan pulse sensor dihubungkan dengan mikrokotroller ESP8266 yang dikoneksikan dengan aplikasi android untuk digunakan dalam pengambilan data shu pada objek. Setelah pengambilan sensor data tersebut kemudian ditampilkan pada aplikasi android.

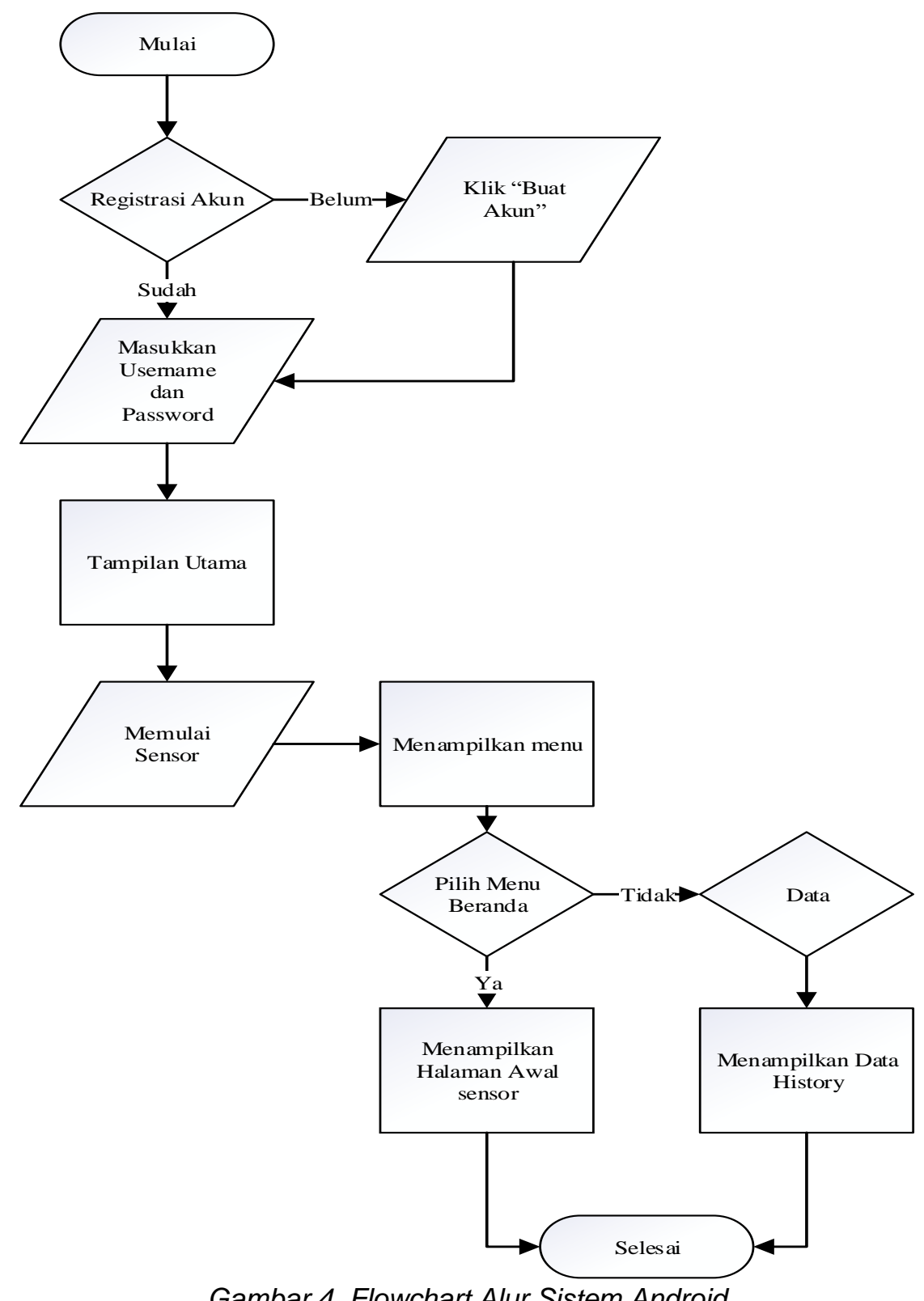

Pada Gambar 4 adalah flowchart alur sistem android yang menjelaskan alur kerja sistem pada android yang diawali dengan register pengguna apabila belum memliki akun. Kemudian pengguna diharuskan login untuk mengakses apliksi ini.

\subsection{Rancangan Apliksi Android}

Pembuatan form aplikasi android didesain semudah mungkin agar mudah digunakan. Form utama dari aplikasi android merupakan form yang berfungsi sebagai display output yang dikirim dari ESP8266.

1. Dimulai dari menu login untuk pengguna aplikasi sistem android ini. Masukkan username dan password. Apabila pengguna belum memiliki username dan password harus mendaftar sebagai pengguna baru. 
2. Untuk pengguna baru yang diharuskan untuk mendaftarkan diri untuk bisa menggunakan aplikasi android. Data yang dimasukkan agar dapat dipakai ketika login. Data yang dimasukkan pun untuk mengetahui siapa saja pengguna dari aplikasi ini.

3. Tampilan utama yakni perhitungan untuk sensor dari detak jantung dan suhu tubuh.

4. Tampilan menu yang ini ada beranda untuk kembali kehalamn utama yaitu sensor, kemudian ada data untuk menampilkan hasil sensor.

5. Tampilan pada menu data terdapat keterangan tanggal dan data untuk menampilkan kapan hasil sensor itu dan hasil perkiraan angka dari sensor tersebut.

\subsection{Pengujian}

Pengujian sistem terdiri dari pengujian alat dan pengujian aplikasi android. Pengujian alat yakni untuk menguji alat sensor dan modul ESP8266, apakah alat bekerja dengan baik atau tidak. Dan untuk pengujian apliksi android untuk mengetahui apakah menu dan tampilan sudah sesuai atau belum.

\section{Hasil Penelitian dan Pembahasan} penelitian.

Setelah dilakukan uji coba, analisa dilakukan terhadap hasil yang didapatkan dalam

\subsection{Implementasi Perangkat Keras dan Perangkat Lunak}

Perangkat keras yang diperlukan untuk implementasian pada arsitektur yang telah dirancang sebelumnya adalah sebgai berikut:

1. ESP8266

2. Pulse Sensor

3. Ds18b20

4. Laptop/ Komputer

5. Smartphone

Perangkat Lunak yang diperlukan:

1. Operating System Windows 10,64-bit versions

2. Ionic

3. Node JS

4. Mongo DB

\subsection{Implementasi Sistem}

Implementasi sistem dibawah ini merupakan implementasi berdasarkan perancangan pada tahap sebelumnya. Implementsi dua yaitu implementasi pada alat dan perangkat lunak.

\subsubsection{Implementasi Alat}

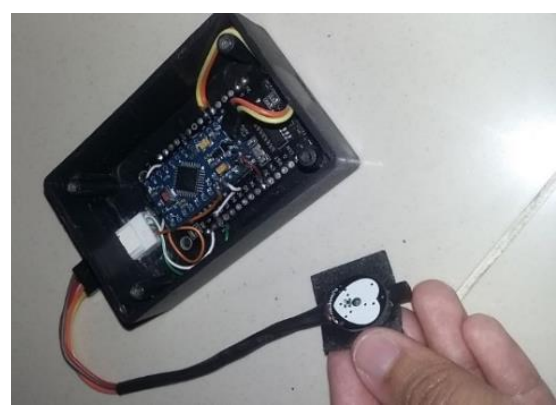

Gambar 5. Rangkaian Alat

Implementasi pada alat sensor seperti pada Gambar 5 merupakan rangkaian dari ESP8266, Pulse Sensor (sensor detak jantung) dan ds18b20 (sensor suhu tubuh).

\subsubsection{Implementasi Android}

Implementasi aplikasi android ini membahas tentang halaman utama (beranda) dari aplikasi sistem ini dapat dilihat pada Gambar 6. 


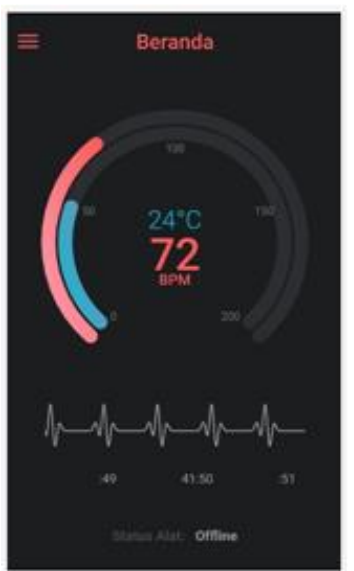

Gambar 6. Tampilan Beranda

\subsection{Skenario Pengujian}

Skenario pengujian dilakukan dari segi beberapa kebutuhan dari pengujian pulse sensor, pengujian ds18b20, dan jarak antara alat dan aplikasi.

\subsubsection{Pengujian Pulse Sensor}

Pengujian dilakukan dengan menghitung jumlah detak jantung per menit terhadap 3 responden yang dilakukan dengan perbandingan alat sistem dengan stetoskop. Tabel 1 berikut hasil pengujian.

Tabel 1. Hasil Pengukuran Detak Jantung Per Menit

\begin{tabular}{ccccc}
\hline \multirow{2}{*}{ No. } & \multirow{2}{*}{ Nama } & \multicolumn{2}{c}{ Pengukuran Detak Jantung } & \multirow{2}{*}{ Error \% } \\
\cline { 2 - 4 } & Objek 1 & 68 & Stetoskop & \\
\hline 1 & Objek 2 & 79 & 66 & 2.08 \\
2 & Objek 3 & 79 & 80 & 1.2 \\
3 & \multicolumn{2}{c}{ Rata-rata Error (\%) } & 77 & 2.03 \\
\hline \multicolumn{4}{c}{}
\end{tabular}

Tabel 1 menunjukkan data dari hasil pengujian terhadap detak jantung dengan 3 responden yang dilakukan dengan alat yang telah dibangun dan dibandingkan dengan alat secara medis. Presentase error hanya $1.77 \%$, maka alat dalam tugas akhir ini tergolong stabil dalam pengukuran dan cukup akurat menjalankan fungsinya sebagai alat untuk memonitoring detak jantung.

\subsubsection{Pengujian DS18B20}

Pengujian dilakukan dengan menghitung jumlah suhu tubuh per menit terhadap 3 responden yang dilakukan dengan perbandingan alat sistem dengan termometer. Tabel 2 berikut hasil pengujian.

Tabel 2 menunjukkan data dari hasil pengujian terhadap suhu tubuh dengan 3 responden yang dilakukan dengan alat yang telah dibangun dan dibandingkan dengan alat secara medis. Presentase error hanya $0.46 \%$, maka alat dalam tugas akhir ini tergolong stabil dalam pengukuran dan cukup akurat menjalankan fungsinya sebagai alat untuk memonitoring suhu tubuh.

Tabel 2. Hasil Pengukuran Suhu Tubuh

\begin{tabular}{ccccc}
\hline \multirow{2}{*}{ No. } & \multirow{2}{*}{ Nama } & \multicolumn{2}{c}{ Pengukuran Suhu Tubuh } & \multirow{2}{*}{ Error \% } \\
\cline { 2 - 3 } & Objek 1 & 35.4 & Termometer & \\
\hline 1 & Objek 2 & 37.1 & 35.6 & 0.38 \\
2 & Objek 3 & 36.2 & 37 & 0.42 \\
3 & \multicolumn{2}{c}{ Rata-rata Error (\%) } & 0.58 \\
\hline \multicolumn{4}{c}{}
\end{tabular}




\subsubsection{Pengujian Jarak}

Pengujian dilakukan dengan cara menghitung antara pengukuran jarak dari sistem alat ke aplikasi android.

Tabel 3. Pengujian Jarak Alat dengan Aplikasi

\begin{tabular}{ccc}
\hline No & Jarak $(\mathrm{m})$ & Keterangan \\
\hline 1 & 1 & Sukses \\
2 & 2 & Sukses \\
3 & 3 & Sukses \\
4 & 4 & Sukses \\
5 & 5 & Sukses \\
6 & 6 & Sukses \\
7 & 7 & Sukses \\
8 & 8 & Sukses \\
9 & 9 & Sukses \\
10 & 10 & Sukses \\
11 & 11 & Sukses \\
12 & 12 & Sukses \\
13 & 13 & Sukses \\
14 & 14 & Sukses \\
15 & 15 & Sukses \\
16 & 16 & Sukses \\
\hline
\end{tabular}

Tabel 3 menunjukkan data dari hasil pengujian terhadap jarak sistem yang telah dibangun dengan aplikasi yang telah dibuat. Dalam jarak sampai 16 meter masih sukses untuk pengiriman data hasil sensor bisa tergolong stabil dalam pengukuran dan cukup akurat menjalankan fungsinya sebagai alat untuk memonitoring.

\section{Kesimpulan}

Berdasarkan proses observasi, analisis, dan implementasi pada tugas akhir ini, ada beberapa kesimpulan yaitu:

1. Dengan adanya alat pengukur detak jantung dapat memonitoring detak jantung dan suhu tubuh secara langsung dan berkala.

2. Semua hasil perhitungan dari sensor ditampilkan secara real pada sebuah aplikasi yang berjalan di platform android.

3. Hasil pengukuran detak jantung dan suhu tubuh yang digunakan pada laporan tugas akhir ini sangat bergantung pada nilai / input dari pulse sensor dan ds18b20, nilai tegangan inputm dan hubungan hardware dan software.

\section{Referensi}

[1] V. Suryani, A. Rizal, H. Diskusi, and P. Simulasi, "Analisis Kelayakan Penggunaan Protokol Wireless Untuk Transmisi Data Pada Wireless Body Area Network ( Wban )," pp. 3-6.

[2] M. I. Sani, "Implementasi ZigBee Transceiver untuk Akuisisi Data Sensor Inersia pada Wireless Body Area Network ( WBAN )," J. Infotel, vol. 9, no. 1, pp. 48-55, 2017.

[3] P. Ilmiah and E. Riyanto, "Berbasis Arduino Serta Smartphone Android Disusun sebagai salah satu syarat menyelesaikan Program Studi Strata I pada Jurusan Teknik Elektro Fakultas Teknik," 2016.

[4] A. B. Wijaya and A. S. Khalilullah, "Seminar Proyek Akhir Jurusan Teknik Telekomunikasi PENS-ITS 2010," Ranc. Bangun Alat Pengukur Detak Jantung dan Suhu Tubuh Mns. Berbas. Komun. Bluetooth, p. 4, 2010.

[5] M. F. R. F and A. S. T. Manusia, "Rancang Bangun Prototipe Monitoring Suhu Tubuh Nabusia Berbasis O.S Android Menggunakan Koneksi Bluetooth (Prototype Design Human Body Temperature Monitoring Based Android O.S Using Bluetooth Connection )," J. Tek. Pomits, vol. 2, no. 1, pp. 123-126, 2013. 
REPOSITOR, Vol. 2, No. 3, Maret 2020: 269-276 